\title{
Christopher J. Neely
}

Christopher J. Neely is an economist at the Federal Reserve

Bank of St. Louis. Kelly M. Morris provided research assistance.

\section{Realignments of Target Zone Exchange Rate Systems: What Do We Know?}

Chief Witch: Yes, that's right.

MacBeth: I understand you can foretell the future.

- From a BBC Radio Program, June 1968

During the French revolution such people were known as agioteurs (speculators)

- and they were guillotined.

- Michel Sapin, French Minister of Finance, speaking of currency traders ${ }^{1}$

INCE MARCH 1979, most of the nations of the European Union have participated in a "target zone" system of exchange rate management known as the Exchange Rate Mechanism (ERM) of the European Monetary System (EMS). Although the target zones of the ERM have weathered many adjustments since their inception, speculative currency attacks in September 1992 and August 1993 led to the de facto suspensi on of the system. The United Kingdom and Italy suspended their participation in the ERM on September 17, 1992. After August 1993, the bands were broadened sufficiently to functionally alter the character of the system. These recent crises have focused attention on the stability of not only the ERM, but of target zone systems generally.
A target zone is a hybrid exchange rate regime, a compromise between floating and completely fixed exchange rates. In a target zone system, monetary authorities pledge to keep the exchange rate with a particular foreign currency, or basket of currencies, within given margins around a central parity. At times, the authorities may also choose to realign the central parity. Advocates argue that target zones blend the advantages of fixed exchange rates and flexible exchange rate systems. ${ }^{2}$ Krugman and Miller (1992) point out that the original justification for constraining EMS exchange rates within target zones was to reduce exchange rate volatility, which contributes to uncertainty and risk in international trade and investment. ${ }^{3}$ More recently, a desire to "borrow"

\footnotetext{
1 Macleod (1992).

2 See Corbae, Ingram and Mondino (1990) for a theoretical development of one justification for target zones.
} 
the low inflation reputation of a foreign central bank (for example, the Bundesbank) has been frequently cited as an advantage of target zones. Compared to completely fixed rates, target zones allow central banks greater scope for monetary independence. ${ }^{4}$ Paradoxically, the exercise of independence may contribute to expectations of real ignment, which produce a "speculative attack," in which speculators refuse to hold one of the currencies at any exchange rate in the target zone. A successful speculative attack necessitates a realignment of the central parity, thus thwarting the goal of stability of the exchange rate. ${ }^{5}$

Researchers would like to understand the circumstances associated with speculative attacks and the realignments of central parities within a target zone for several reasons. If financial market participants could forecast realignments, they could profit from the large changes in asset prices. For example, it is estimated that investor George Soros made $\$ 1$ billion speculating against the pound and the lira as a result of the crisis of 1992. Monetary authorities have a different rationale for anal yzing real ignments: They wish to be able to manage the economy more effectively. Ideally, they would like to maintain stable exchange rates and low inflation while also retaining sufficient monetary flexibility to conduct countercyclical stabilization policy. Although there is no consensus on the microeconomic benefits of exchange rate stability versus the macroeconomic benefits of domestic stabilization policy, realignments produce uncertainty about the value of internationally held assets/investments which policymakers would like to avoid.

Economists have had little success in forecasting exchange rates at short horizons. Yet, there is evidence (Mizrach, 1993c) that we can forecast target zone real ignments over a short interval using information from interest rates, inflation, and the position of the exchange rate in the target zone. This article surveys the recent research on forecasting realignments and estimating the credibility of target zones. To facilitate understanding of the functioning of exchange rate target zones, the next section of this article presents a simple monetary model of exchange rate deter- mination. Section three discusses the functioning of target zone systems. The empirical literature on realignments and credibility of target zones is surveyed in section four. The final section summarizes the conclusions of the literature and suggests future research.

\section{EXCHANGE RATE DETERMINATION}

Target zones are created to stabi lize exchange rates. It is necessary to understand exchange rates and the market forces that determine them to understand the forces behind realignments of target zones. To give the reader an idea of what an exchange rate within a target zone looks like, the top panel of Figure 1 depicts the log of the deutsche mark per franc exchange rate from March 1979 to July 1993. As the relative price of money, the exchange rate is determined by market "fundamentals," that is, output, price levels, money supplies and interest rates. In the short run, a relation called uncovered interest parity (UIP) is thought to control exchange rates. In the long run, theory suggests that the rel ative prices of goods determine exchange rates through a relation called purchasing power parity (PPP).

\section{Uncovered Interest Parity}

Markets for financial instruments have low transactions costs and very good information, so small changes in expected asset returns cause large movements of capital. Expected asset returns drive exchange rate movements because investors must exchange currencies to purchase foreign financial instruments or repatriate earnings from international investments. For example, if French interest rates exceed those of Germany, a German investor might choose to exchange deutsche marks for francs at the current exchange rate, buy French financial assets (such as government bonds) that pay a higher interest rate, and then repurchase deutsche marks with the francs when the bond matures.

Of course, if French bonds pay a higher interest rate, why would any investor choose to buy German bonds? The answer is that there are two forms of returns from international investments, the return on the investment itself and

Henderson (1978), Flood and Garber (1984) and Obstfeld

\footnotetext{
${ }^{4}$ In this context, independence means freedom to use monetary policy for internal, rather than external, goals. The limits of this type of monetary independence in a target zone are explored by Kool (1993). Pollard (1993) examines the benefits of freeing central banks from political pressures.

${ }^{5}$ The theoretical literature on speculative attacks on fixed exchange rate systems is well-developed. Salant and
}

\section{(1984 and 1986) have made important contributions.}


the return on the exchange rate. Generally speaking, the expected return for international assets should be the same for all assets. ${ }^{6}$ A simple example illustrates the manner in which the asset returns and expected exchange rate movements interact.

The expected gross return in deutsche marks for a German investor who invests DM 1000 in German bonds during period $t$, for $\tau$ years, compounded annually, is simply

\section{(1) Expected gross return for investing in} German Bonds $=1000 \cdot\left(1+\mathrm{i}_{\mathrm{t}}^{\mathrm{Ge}}\right)^{\tau}$,

where $\mathrm{i}_{t}$ Ge is the annual rate of interest on a German bond. ${ }^{7}$ If the same investor exchanged deutsche marks for francs, bought and held French bonds, then exchanged the earnings in francs for deutsche marks, the expected gross return would be:

(2) Expected gross return for investing in

$$
\begin{aligned}
\text { French Bonds } & =\frac{1000}{\mathrm{e}_{\mathrm{t}}} \cdot\left(1+\mathrm{i}_{\mathrm{t}}^{\mathrm{Fr}}\right)^{\tau} \cdot \mathrm{E}_{\mathrm{t}}\left(\mathrm{e}_{\mathrm{t}+\tau}\right) \\
& =1000 \cdot\left(1+\mathrm{i}_{\mathrm{t}}^{\mathrm{Fr}}\right)^{\tau} \cdot\left(\mathrm{E}_{\mathrm{t}}\left[\frac{\mathrm{e}_{\mathrm{t}+\tau}}{\mathrm{e}_{\mathrm{t}}}\right]\right) .
\end{aligned}
$$

Define the log of the expected return on the exchange rate (deutsche marks per franc) from period " $\mathrm{t}$ " to period " $\mathrm{t}+\tau$ " by ${ }^{8}$

$$
\text { (3) } \begin{aligned}
\mathrm{E}_{\mathrm{t}}\left[\Delta \mathrm{s}_{\mathrm{t}+\tau}\right] & \equiv \ln \left(\mathrm{E}_{\mathrm{t}}\left[\frac{\mathrm{e}_{\mathrm{t}+\tau}}{\mathrm{e}_{\mathrm{t}}}\right]\right) \\
& =\ln \left(\mathrm{E}_{\mathrm{t}}\left[\mathrm{e}_{\mathrm{t}+\tau}\right]\right)-\ln \left(\mathrm{e}_{\mathrm{t}}\right) .
\end{aligned}
$$

For expected returns to be equal ized, a higher French interest rate must be offset by an expected depreciation in the exchange rate (fewer deutsche marks per franc in the future). If nominal interest rates are not too large, equating the right sides of equations 1 and 2 and using definition 3 gives us an approximation to the expectation of the exchange rate change next period:

(4) $\frac{\mathrm{E}_{\mathrm{t}}\left[\Delta \mathrm{s}_{\mathrm{t}+\tau}\right]}{\tau} \approx \mathrm{i}_{\mathrm{t}}^{\mathrm{Ge}}-\mathrm{i}_{\mathrm{t}}^{\mathrm{Fr}}$,

where $\tau$ is the number of years per period. If the periods are months, for instance, $\tau=1 / 12$. Economists call this relationship UIP. ${ }^{9}$ Nations with consistently high inflation rates tend to have higher nominal interest rates (to compensate investors for loss of purchasing power) and depreciating currencies.

Empirical studies have failed to find much support for the UIP hypothesis among flexible exchange rate systems (Froot and Thaler, 1990). This may be due to unrealistic assumptions. UIP assumes that investors are risk-neutral when, in fact, there seem to be time-varying risk premia in the data. Also, there are frequently capital controls in the real world that prevent investors from adjusting their portfolios in response to changes in interest rates or expected exchange rates. Despite the fact that it has a poor record of empirical support among flexible exchange rate systems, UIP is a useful way of thinking about target zone exchange rates. In contrast to previous studies on flexible rate systems, Mizrach (1993a) finds support for UIP in the well-integrated capital markets of the EU.

\section{Purchasing Power Parity}

One can buy goods and services as well as financial assets with money. A higher price level in France means that one can buy fewer goods with a given quantity of francs; each franc is less valuable. PPP says the exchange rate will adjust downwards to reflect higher prices. That is, if France maintains a 10 percent higher infla-

\footnotetext{
${ }^{6}$ This is, of course, a simplification. A more accurate statement would be that the after-tax, risk-adjusted return for different assets must be the same. Koedijk and Kool (1993) compare the profitability of investment strategies in different ERM currencies.

${ }^{7}$ If it were not necessary to consider intervals other than a year, $\tau$ could be set equal to 1 for simplicity.

${ }^{8}$ We will take advantage of the fact that for $-.2<x<.2$, a reasonable approximation is $\ln (1+x) \approx x$. An immediate application of this is $\ln \left(1+i_{t} G e\right) \approx i_{t} G e$. This means that for small percentage changes, the log difference of a variable is approximately the percentage change in the variable. Define $s_{t}=\ln \left(e_{t}\right)$. Using the approximations and the definitions, $\left[\left(e_{t+1} / e_{t}\right)-1\right] \approx \ln \left(e_{t+1} / e_{t}\right)=\ln \left(e_{t+1}\right)-\ln \left(e_{t}\right)$

$$
=s_{t+1}-s_{t}=\Delta s_{t+1} \text {. }
$$

${ }^{9}$ If we were to repeat this example from the point of view of a French investor, we would find an analogous UIP condition
}

which, together with equations 1 and 2, would imply that $E_{t}\left[1 / \Delta s_{t+\tau}\right]=1 / E_{t}\left[\Delta s_{t+\tau}\right]$. Since, in general, $E_{t}\left[1 / \Delta s_{t+\tau}\right] \neq$ $1 / E_{t}\left[\Delta s_{t+\tau}\right]$, UIP cannot hold simultaneously in discrete time for two currencies. This is known as Siegel's paradox. Siegel's paradox was shown to be irrelevant in empirical work by McCulloch (1975). 
tion rate than Germany, its exchange rate will depreciate 10 percent per year in the long run.

A variable useful for measuring changes in relative purchasing power is called the "real exchange rate." The real exchange rate in period $t\left(r x_{t}\right)$ is defined to be:

(5) $r x_{t}=\frac{e_{t} \cdot P_{t}^{F r}}{P_{t}^{G e}}$,

where $\mathrm{P}_{\mathrm{t}}^{\mathrm{Fr}}$ and $\mathrm{P}_{\mathrm{t}}^{\mathrm{Ge}}$ denote the price levels in France and Germany in period $t$, and $e_{t}$ denotes the nominal exchange rate in that period. An increase in the real exchange rate means that the franc becomes more valuable, imports will be cheaper to French consumers but the price of French exports to Germany rises. French goods will become less competitive on the world market. If PPP holds, the real exchange rate will tend to be mean-reverting; it will tend to return to some constant level. ${ }^{10}$ Empirically, evidence supporting PPP is limited, but PPP remains useful for thinking about long-run tendencies in exchange rates. ${ }^{11}$

Both UIP and PPP suggest that a nation which has a consistently more expansionary monetary policy will have a currency that will tend to depreciate. The depreciation will occur through the inflation premi um built into the nominal interest rate according to UIP, and through rising prices of domestic goods which require that the home currency lose value rel ative to foreign currencies to keep the real exchange rate constant according to PPP.

\section{TARGET ZONE EXCHANGE RATE SYSTEMS}

A target zone is a hybrid exchange rate regi me, a compromise between managed floating and completely fixed exchange rates. In a managed float, monetary authorities may or may not, at their discretion, intervene to control the rate of exchange. If monetary authorities fix the exchange

\footnotetext{
${ }^{10}$ Roughly speaking, a random variable, such as the real exchange rate, that can be forecasted accurately far into the future is said to be mean-reverting. A mean reverting process is one that will tend to return its usual value in the long run.

${ }^{11}$ Barriers to trade, transportation costs, differing baskets of goods across countries, imperfect competition, nontraded goods and differentiated goods may all contribute to weakening the effects of PPP. For an investigation of PPP within the EMS, see Edison and Fisher (1991). Coughlin and Koedijk (1990) review the literature on the determination of the real exchange rate in the long run. Dueker (1993) investigates PPP with the more recent econometric technique of fractional integration.
}

rate, they willingly buy or sell their own currency in unlimited quantities at the fixed rate. A target zone exchange rate system has el ements of each. Monetary authorities pledge to intervene in the market to keep the domestic exchange rate with a particular foreign currency, or basket of currencies, within narrow margins around a central parity. Realignments occur when central banks are unwilling (or find it too costly) to conduct the interventions necessary to preserve the target zone.

\section{The ERM}

The most important target zone, the ERM, has operated since March 1979 to prevent what was perceived to be the excessive volatility in exchange rates that had prevailed in the 1970s. ${ }^{12}$ The target zones for each currency were initially established at \pm 2.25 percent around the bi lateral central parities for most of the currencies, \pm 6 percent for the more volatile currencies such as the Italian lira, Spanish peseta, British pound and Portuguese escudo.

It is common to divide the period of the ERM into three sub-periods. The first period extends from the inception of the ERM in March 1979 until the end of 1983. The target zones were characterized by lack of credibility and frequent devaluations during this period. The second period lasted from 1984 to the end of 1991 and coincided with increasing confidence in the ERM and greater convergence in the economic fundamentals of the member nations. Figure 1 illustrates four devaluations of the French franc relative to the deutsche mark in the first period and only two in the second period. ${ }^{13}$ It was widely thought in 1989 and 1990 that the target zones had become permanent and would never be realigned but would simply lead into monetary union, a system of permanently fixed exchange rates with one monetary authority. This would effectively mean one currency. Events would prevent this smooth transition.

\footnotetext{
${ }^{12}$ For more information on the history and practices of the EMS, see Fratianni (1988), Ungerer, Hauvonen, LopezClaros and Mayer (1990), Zurlinden (1993), Edison and Fisher (1991), Bean (1992) and Higgins (1993).

${ }^{13}$ The data in Figure 1 ends shortly before the widening of the target zones to \pm 15 percent for all rates except the guilder/deutsche mark in August 1993, which was a de facto realignment and the practical suspension of the system. See Zurlinden (1993) for a full description of the evolution of the bilateral central parities in the ERM.
} 
Figure 1

Deutsche Mark Per Franc Exchange Rate (March 1979 through July 1993)

In levels of normalized exchange rates

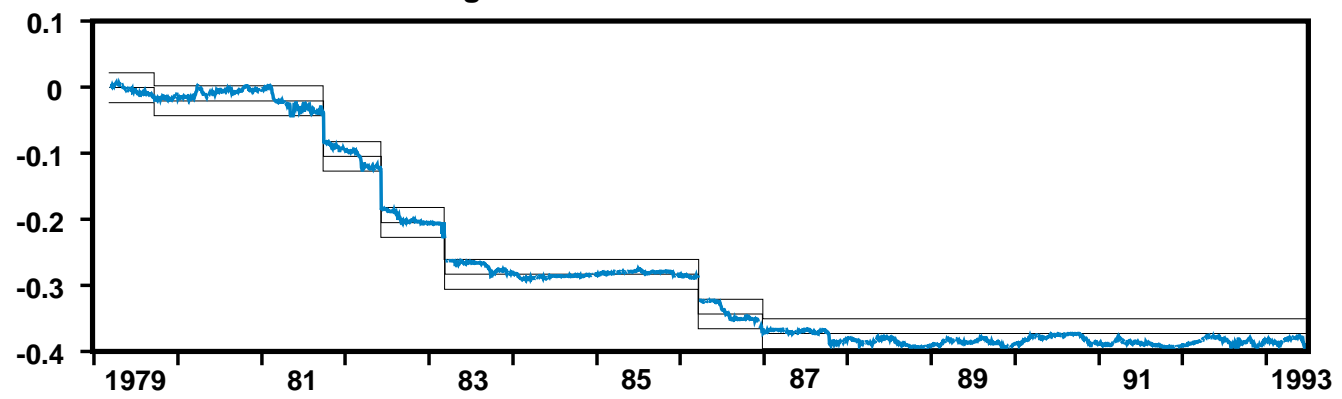

French-German 3-Month Interest Rate Differentials (March 1979 through July 1993)

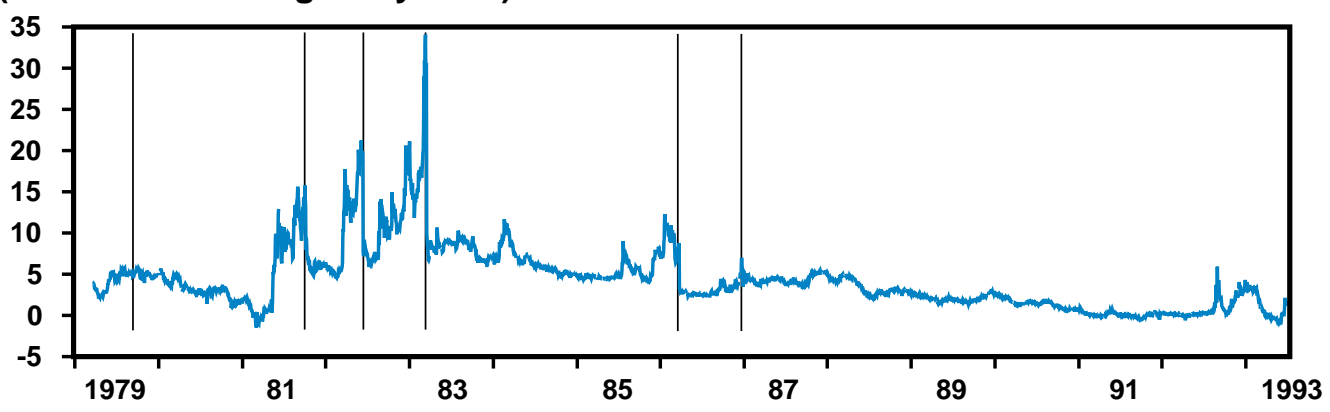

The third period for the system was the time leading to the crises and suspension of the system. German unification and the recession in Europe are widely accepted as the underlying causes of the crises of September 1992 and August 1993. ${ }^{14}$ Reunification opened up major investment opportunities in the undeveloped East, increasing the demand for deutsche marks and required the German government to spend a great of money to subsi dize the East and bring it up to western standards. The government al so agreed to convert East German ostmarks to West German deutsche marks on a very generous 1:1 basis. ${ }^{15}$ This one-time expansion of the money supply raised fears of inflation. High German interest rates put upward pressure on the deutsche mark. At the same time, a recession was ravaging Europe, striking Britain and Italy particularly hard. Pressure mounted on the Bank of England and the Bank of Italy to lower interest rates to fight their recessions, while the Bundesbank resisted lowering money market interest rates due to fear of inflation. Furthermore, the Danish rejection of the Maastricht treaty in June 1992 put the European Monetary Union (EMU) in jeopardy. This was the catalyst for the speculative attack of September 1992, which drove the British pound and the Italian lira from the ERM. ${ }^{16}$ The pressure mounted over the next year as speculation against the remaining weaker currencies continued.

Finally, in August 1993, the ERM was effectively suspended as bilateral bands were widened from \pm 2.25 percent to \pm 15 percent for all the rates except the Dutch guilder/deutsche mark rate.

${ }^{14}$ Higgins (1993) and Zurlinden (1993) examine the events leading to the collapse of the ERM in more detail.

${ }^{16}$ See Zurlinden (1993) for a detailed description of the experiences of the British pound in the ERM.

15 The exchange of deutsche marks for ostmarks was not unlimited on a 1:1 basis. Bofinger (1990) provides a more detailed account of these events. 
THE CREDIBILITY OF TARGET ZONES: FORECASTING REALIGNMENTS

Realignments have been a common feature of target zone systems. This section surveys the research on realignments of target zones conducted in the last several years. This literature has focused on a number of related issues such as the credibility of a particular target zone, the probability of a real ignment and the expected size of a realignment. Economi sts have had little success in forecasting financial variables such as exchange rates. ${ }^{17}$ Target zone exchange rates may be different, however. Central banks manage exchange rates to promote full empl oyment or low inflation or some other economic goal; they do not conduct monetary policy for profit. Knowledge of economic variables may be used to forecast their policies. Expectations that the monetary authorities will prefer to real ign rather than defend the target zone will lead investors to demand an interest rate premium to hold the weak currency. Therefore, clear expectations of a devaluation will be accompanied by a high interest rate differential between the currencies. ${ }^{18}$

\section{The Simplest Test of Target Zone Credibility}

This test is constructed to evaluate a weak currency that is expected to stay the same or depreciate. Recall that we devel oped a forecast for expected future exchange rate changes based on interest rate differential s, UIP:

(6) $\frac{\mathrm{E}_{\mathrm{t}}\left[\Delta \mathrm{s}_{\mathrm{t}+\tau}\right]}{\tau}=\mathrm{i}_{\mathrm{t}}^{\mathrm{Ge}}-\mathrm{i}_{\mathrm{t}}^{\mathrm{Fr}}$.

The intuition behind equation 6 is that investors must be compensated by a higher interest rate for hol ding assets denomi nated in a currency that is expected to lose value (depreciate).

In a target zone, the most that the exchange rate could depreciate without a real ignment is the distance from the exchange rate to the lower bound. Denote this distance in percentage terms (it must be a nonpositive number):
(7) $\mathrm{d}_{\mathrm{t}}=\frac{\mathrm{e}}{\mathrm{e}_{\mathrm{t}}}-1 \approx \underline{\mathrm{s}}-\mathrm{s}_{\mathrm{t}}$,

where $\mathrm{e}$ is the lower bound of the target zone, $\underline{\mathrm{s}}=\ln (\underline{\mathrm{e}})$ and $\mathrm{s}_{\mathrm{t}}=\ln \left(\mathrm{e}_{\mathrm{e}}\right)$. If the target zone is perfectly credible (no probability of a realignment), the expected depreciation in the exchange rate can be no greater than the distance from the exchange rate to the bottom of the band. That is, for all period lengths we must have

(8) $E_{t}\left[\Delta s_{t+1}\right] \geq d_{t}$.

In a perfectly credible target zone, at a forecast horizon of length $(1 / \tau)$, we must have

(9) $\tau \cdot\left(\mathrm{i}_{\mathrm{t}}^{\mathrm{Ge}}-\mathrm{i}_{\mathrm{t}}^{\mathrm{Fr}}\right) \geq \mathrm{d}_{\mathrm{t}}$.

As $\tau$ goes to zero, that is, as the forecast horizon becomes arbitrarily short, equation 9 must hold; the right side is less than or equal to zero and the left side is going to zero. If equation 9 fails to hold, we can conclude the target zone is not perfectly credible; deval uation is consi dered possible.

The converse is not true, however. There could be significant real ignment expectations with equation 9 still holding. For example, suppose that the deutsche mark per franc rate is currently at central parity so $\mathrm{d}_{\mathrm{t}}=-2.25$ percent, $\mathrm{i}_{\mathrm{t}} \mathrm{Fr}=4$ percent and $\mathrm{i}_{\mathrm{t}} \mathrm{Ge}=2$ percent. Further, investors know it to be equally likely that either there will be no realignment and the exchange rate will be exactly the same a year $(\tau=1)$ from now or that there will be a real ignment and the exchange rate will be exactly 3 percent lower. That means that in this case, equations 8 and 9 would hold but the target zone is not perfectly credible since there is a 50 percent chance of a devaluation (realignment downward).

Formal tests of target zone credibility or realignment probabilities are usually based on the information content of interest rate differentials. The greater the risk of deval uation, the higher the difference in interest rates. An example of the relation between exchange rates and

18 There are other methods for determining the credibility of target zones, such as those in Koedijk and Kool (1993), but this article will focus on those methods using interest rate differentials. the future movement of an asset price (for example, an unusual increase in a stock price) based on public information, that person would borrow money to buy as much stock as possible immediately, driving the price up right away. This is a simple version of the "efficient markets hypothesis." If price changes could be easily anticipated, they would already have happened. 
Figure 2

\section{Deutsche Mark/Franc Within the Band Minus Adjusted Interest Differentials}

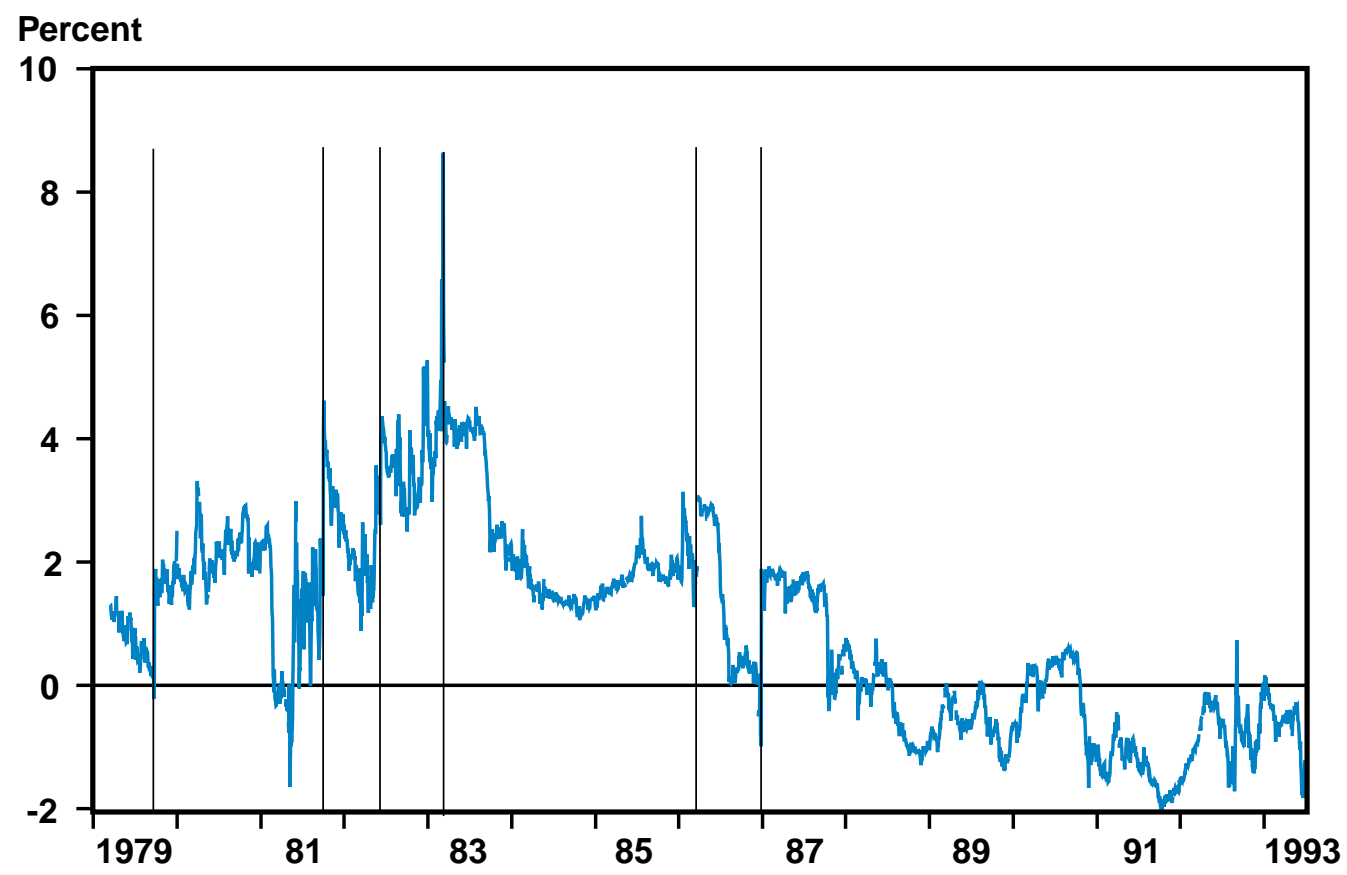

interest rate differentials is shown in Figure 1.

The top panel shows the time series of the exchange rate with the deval uations and the bottom panel shows the corresponding series of the French three-month interest rates minus German three-month interest rates. ${ }^{19}$ The interest rate differential was al ways greater than 0 ; the expectation was al ways that the French franc would depreciate. The bottom half of Figure 1 shows that interest rate differentials tend to widen before realignments (vertical lines).

Figure 2 displays the time series of the deutsche mark per franc exchange rate within the target zone minus the adjusted three-month interest rate differential. This series is equival ent to the guaranteed excess return from investing in French securities over German securities conditional on the band remaining intact. In the notation used above, it is

(10) $d_{t}-\tau \cdot\left(i_{t}^{G e}-i_{t}^{F r}\right)$.

This variable indicates a lack of credibility at the three-month horizon for the target zone when it is greater than zero. This is the "simplest test" of target zone credibility. Thus, Figure 2 shows the target zone lacked credibility most of the time in the early 1980s, gradual ly falling bel ow zero later in the decade as French inflation fell.

In "The Simplest Test of Target Zone Credibility," Lars Svensson (1991) uses equation 9 to examine if interest rates were high enough to conclude that there must be some deval uation expectation for the Swedish target zone from 1987 to 1990. The data are monthly. During the period of Svensson's study, Sweden had a unilateral target zone with a trade weighted "basket" (or weighted average) of the currencies of its 15 largest trading partners. Hence, the relevant exchange rate is now measured in basket units per krona and the respective interest rates are in basket units and krona. The width of the band was 1.5 percent during this period. Svensson plots the return available on domestic securities (for 12-month maturities) against the maximal return (in Swedish krona) on the weighted basket of foreign securities,

${ }^{19}$ The periods of realignments are marked in the bottom panel by vertical lines. 
assuming the target zone would remain intact. He found the Swedish target zone lacked credibility with the ECU for securities with a 12-month horizon from the third quarter of 1989 until the end of the sample in 1990.

The hypothesis of UIP is used to investigate credibility in the same way as the "simplest test." Recall that UIP expressed the expected movement in (basket units per Swedish krona) exchange rates as:

(11) $\mathrm{E}_{\mathrm{t}}\left[\Delta \mathrm{S}_{\mathrm{t}+\tau}\right]=\tau \cdot\left(\mathrm{i}_{\mathrm{t}}^{\text {Basket }}-\mathrm{i}_{\mathrm{t}}^{\mathrm{Sw}}\right)$.

This expression is al so called the expected rate of deval uation. By using the interest rates for securities of different maturities, Svensson is able to construct a series of forecasts for the future val ue of the exchange rate. For example, the forecast for the exchange rate in two years was constructed using the 24-month Euro-currency interest rates for the basket of currencies and the Swedish krona in equation 11 to get the expected change in the weighted exchange rate over that period. If the forecasted exchange rate fell outside the target zone for a particular maturity at some point, the target zone was said to lack credibility at that forecast horizon.

Svensson used maturities of 12,24 and 60 months over the sample period to conclude that while the market generally found the Swedish target zone to be credible in the short run, there was strong evidence that the market also al ways bel ieved that devaluation within a longer horizon (24 to 60 months) was a distinct possibility. Expected exchange rates al ways fell outside the target zone for those maturities for the sample period.

\section{Mean Reversion Within the Target Zone}

A major problem with using UIP to estimate the credibility of target zones is that it predicts movements in the exchange rate, not the central parity. The movement of the exchange rate within the band, especially at short horizons, could account for much or all of the interest rate differential. At longer horizons, the interest yield for securities gets larger (as more interest accrues over time) but the exchange rate within the band is still bounded. For example, if the target zone is 2.25 percent wide (as were the ERM target zones before August 1993) and the exchange rate is at central parity, the simplest test tells us that the interest rate differential on 12-month securities would have to exceed 2.25 percentage points (the width of the band) before we could reject the idea that the target zone is perfectly credible. But, the same test tells us the annual ized interest differential for three-month securities would have to exceed 9 percentage points before we could reach the same conclusion. ${ }^{20}$

To more accurately estimate the credibility of the target zone, at short horizons, it is necessary to estimate the movement of the exchange rate within the band. Investigating this matter, Rose and Svensson (1991) find that daily deutsche mark per franc rates within the band tend to be mean-reverting, that is, they tend to come back to central parity if they are away from it. The mean reversion is due to the fact that monetary authorities will usually defend the target zone by intervening to move the exchange rate back to the center of the target zone if it approaches the edges.

To explain how movements of the exchange rate within the band are forecasted, define the log of the position of the exchange rate within the band as

(12) $x_{t}=s_{t}-C_{t}$,

where $c_{t}$ is the log of the central parity of the band at time t. Note that $x_{t}$ may be positive or negative. Of course, one may rewrite the exchange rate as the sum of the central parity and the position within the band as

(13) $s_{t}=x_{t}+c_{t}$,

and by taking differences (percentage changes) of this equation over time we get

(14) $\Delta \mathrm{s}_{\mathrm{t}}=\Delta \mathrm{x}_{\mathrm{t}}+\Delta \mathrm{C}_{\mathrm{t}}$.

Using the UIP condition stated earlier and rearranging terms, we may express the expected change in central parities (the expected realignment) as

(15) $\mathrm{E}_{\mathrm{t}}\left[\Delta \mathrm{C}_{\mathrm{t}+\tau}\right]=\tau \cdot\left(\mathrm{i}_{\mathrm{t}}^{\text {Basket }}-\mathrm{i}_{\mathrm{t}}^{\mathrm{Sw}}\right)-\mathrm{E}_{\mathrm{t}}\left[\Delta \mathrm{x}_{\mathrm{t}+\tau}\right]$.

Equation 15 illustrates that to more accurately predict changes in the central parity (realignments), it

${ }^{20}(12 / 3)^{\bullet} .0225=.09$ 
is necessary to predict the way exchange rates might move within the band.

Rose and Svensson (1991) make the additional assumption that the future movements of the exchange rate within the band might be predicted from present position and other ERM exchange rates with the deutsche mark. They use an ordinary least-squares regression to predict the changes in the exchange rate within the band for the next month $\left(E_{t}\left[\Delta x_{t+r}\right]\right)$. They find that future changes in the exchange rate are dominated by current position within the band. If the exchange rate is near the edges, it will tend to come back to the middle. Other variables, including other ERM exchange rates, lagged changes and higherorder terms were found to be statistically or economically insignificant.

In order to predict the rate of expected realignment $\left(\mathrm{E}_{\mathrm{t}}\left[\Delta \mathrm{c}_{\mathrm{t+ \tau}}\right]\right)$ they substitute the forecast for the change in the exchange rate within the band $\left(\hat{E}_{t}\left[\Delta x_{t+\tau}\right]\right)$ into equation 15 to predict realignments. They report some success, but suggest that since the expected rate of realignment consistently "overpredicts" realignments, private agents may not antici pate real ignments very well. Since their model is based on market expectations-high interest rate differentialsmisprediction by private agents may degrade its performance.

\section{Expectations}

The question of why private agents may fail to antici pate realignments is puzzl ing to economists. Kaminsky (1993) attributes this lack of success in predicting exchange rate movements in general to the fact that agents must "Iearn" about the nature of the economy and the behavior of the monetary authorities. While they are learning, they may make systematic mistakes about the credibility of the authorities or the nature of shocks hitting the economy. The question of how private agents devel op their expectations and beliefs about the economy is an important one. If central banks knew how to influence expectations of devaluation, they could prevent speculative attacks and stabilize the exchange rate.

The UIP relation tells us something about expectations; interest rate differentials forecast expected movement, but the story is not as simple as that presented in section two. Investors care not only about expected profit, but al so about minimizing risk associated with the profit. For instance, German investors buying domestic bonds are sure of their nominal return, but if they buy French bonds, they must al so take the risk that exchange rates will not move as predicted. If the exchange rate depreciates more than expected, they lose money. Because of this risk, investors require a "risk premium" in the form of an especially high interest rate to hold certain currencies. This risk premium may also change over time as economic conditions change and investors perceive more or less risk in the exchange rate. This time-varying risk premi um makes it difficult to accurately esti mate expectations from interest rate differentials.

An obvious way to investigate agents' expectations about the exchange rate is to ask them. Frankel and Phillips (1991) use this method to investigate the hypothesis of increasing EMS credibility after 1987 (until 1991). With the survey data method from the Currency Forecasters' Digest (CFD) as well as the UIP method, Frankel and Phillips examine whether forecasts of future exchange rates fall within the target zone for monthly EMS exchange rates. They consider the main advantage of survey data to be immunity from error due to exchange rate risk premia. The closer the forecast is to the central parity, the more credi ble the target zone. ${ }^{21}$ Prior to 1990, estimates of the expected annual rates of devaluation were about 2-5 percent for most currencies. These estimates tended to overpredict actual devaluations. Their study concludes that between 1987 and 1991, the EMS experienced a significant gain in credibility using one- and five-year horizons. That is, one- and five-year forecasts of the exchange rate move much closer to current central parity after 1987.

UIP and survey data approaches are useful to inform us as to the expectations of market participants with respect to the exchange rate, but they do not tell us how these expectations are formed. Using Swedish data from 1982 to 1991, Lindberg, Svensson and Söderlind (1991) consider this problem of explaining time-varying market deval uation expectations in terms of underlying factors. They first use a variant of the "simplest test" to compute deval uation expectations over time for one-, three-, six- and

${ }^{21}$ Their methods are very similar to Svensson's "simplest test" discussed above. 
12-month forecast horizons. Generally, they were unable to find much incidence of a lack of credibility at short forecast horizons. ${ }^{22}$

Lindberg, Svensson and Söderlind (1991) attribute the failure to find a lack of credibility at shorter horizons to ignoring expected changes within the band. As discussed in the context of mean reversion, changes within the band may be large rel ative to interest rate differentials at short horizons. To get more precise estimates of deval uation expectations, Lindberg, Svensson and Söderlind (1991) required a specification for future values of the exchange rate. Theory suggested starting with a simple log linear specification:

$$
\mathrm{x}_{\mathrm{t}}=\beta_{0}+\beta_{1} \cdot \mathrm{x}_{\mathrm{t}-1}
$$

Although they considered a variety of explanatory variables and methods to esti mate equation 18 and its variants, a simple OLS regression with a Newey-West correction for conditional heteroskedasticity to the errors worked best for estimating changes within the band. The gains to precision were described as "substantial" for short horizons.

With the new devaluation expectations series, Lindberg, Svensson and Söderlind examine the circumstances around four specific periods of high realignment expectations. The first period, October 1982, was the only time that the target zone was actually real igned. The market seemed to have weakly anticipated it two to three months before it occurred. The high real ignment expectations in the spring of 1985 were ascribed to the election of a new government and uncertainty about the width of the band. ${ }^{23}$ The third period of high real ignment expectations was al so associated with political events, the political crisis and weak economy of the first three quarters of 1990. Finally, high real ignment expectations in the late fall of 1990 were al so imputed to fears that the government would change the target zone before the general el ection of September 1991.

In a more formal investigation of how expectations are formed by political events and macrovariables, Lindberg, Svensson and Söderlind regressed devaluation expectations on variables such as changes in the real exchange rate, parliamentary elections, changes in foreign

22 There was a lack of credibility at all horizons before the only actual devaluation (October 1982) and around the time of an election (September 1985). In addition, the target zone frequently lacked credibility at the 12-month forecast horizon. exchange reserves, unemployment, money growth, government borrowing and the current account. Only changes in the real exchange rate, parliamentary elections and the current account proved to be significant explanatory variables. The coefficients on these significant explanatory variables were unstable over subperiods, however, perhaps indicating the shifting focus of market partici pants as they devel op their expectations.

Rose and Svensson (1993) extended the efforts to learn about the causes and behavior of realignment expectations during the EMS. They regressed real ignment expectations on measures of rel ative money, output, the real exchange rate, inflation, the trade bal ance, reserves and exchange rate volatility within the band. They found no robust link between real ignment expectations and the macroeconomic variables. Use of a vector autoregressive system had no more success. They conclude that there is "no apparent relati onship between macroeconomic variables and credibility" (p. 16).

After examining the behavi or of macroeconomic variables and political events before the currency crises of 1992 and 1993, Rose and Svensson find it difficult to convincingly explain the cause and suddenness of the crises. Although it is easy to claim ex post that the macroeconomic fundamental s dictated a reval uation of the deutsche mark, "it remains a mystery that the deepest financial markets in the world yiel ded so remarkably few indications of an imminent crisis" (p. 26). Furthermore, the weak link between realignment expectations and macroeconomic variables is troubling.

\section{Truncated Data}

An often ignored problem in working with data from target zone exchange rate systems is that the data are "truncated." This is a problem for statistical research on this data; much commonly used statistical theory assumes the distribution of the random variable to be unbounded. Chen and Giovannini (1992) suggest transforming the exchange rate into the following unbounded random variable:

$$
z_{t}=\ln \left[\frac{L+X_{t}}{L-x_{t}}\right]
$$

\footnotetext{
${ }^{23}$ The width of the target zone was not public information at this time.
} 
where $L=\ln \left(\overline{\mathrm{e}} / c_{t}\right)$, $\overline{\mathrm{e}}$ is the upper edge and $c_{t}$ is the central parity of the target zone.

Working with the transformed random variable $\mathrm{z}_{\mathrm{t}}$, Chen and Giovannini investigate target zone credibility in the usual ways using monthly data from the ERM and the Bretton Woods system. ${ }^{24}$ With a linear prediction of the exchange rate within the target zone, they estimate band credibility from the UIP relationship. Their confidence intervals for the expected changes within the band are actual ly constrained by the band (by construction) whereas the confidence intervals for the untransformed variables frequently fall outside the target zone. This property rules out nonsensical values for expected changes within the band and means a better estimation of the process. As in other studies, they are able to frequently reject perfect credibility for ERM zones during the 1980s.

\section{The Probability and Size of Realignments}

The simplest test of target zone credibility only predicts the expected rate of devaluation $\left(E_{t-1}\left[\Delta s_{t}\right]\right)$ over a period of time. It does not predict the probability of realignment over that period, nor does it predict the size of a real ignment conditional on one occurring. The simplest test is unable to differentiate between an al most certain small realignment and a low probability of a large real ignment.

Recently, Mizrach (1993b and 1993c) has used a hybrid Markov-Probit model to estimate the probability of realignment and the expected size, conditional on an occurrence. The probability of realignment estimated by a probit model uses the log of the position of the exchange rate within the band, and the domestic yield curve as independent variables. The log of the exchange rate within the band is again modeled as a linear autoregression; lagged values of $x_{t}$ predict future values. The expected size of an exchange rate movement, conditional upon a realignment, is all owed to depend on the real exchange rate. Nonlinear least-squares were used to estimate the model on daily data from the ERM, the FF/DM and IL/DM exchange rates.

Mizrach found strong evidence of mean reversion within the band; the parameter estimates suggest that any deviation from central parity would be expected to be cut in half in a week or two. The model forecasts systematical ly larger realignments than actual ly occurred for both the franc and the lira. The probit parameters all were significant and had the appropriate sign. Restrictions of constant realignment risk and no mean reversion were strongly rejected.

It was found that, typically, probabilities were at usual levels up until a month before a realignment and then began climbing upwards. The short nature of the warning time provided by the model leads Mizrach to conclude that real ignments "surprised" market participants and policymakers. Mizrach concludes that his model supports the hypotheses of mean reversion within the band and produces credible estimates of time-varying realignment risk.

\section{The Role of the Dollar}

The empirical work discussed above does not use a potentially important indicator of realignments, weakness in the U.S. dollar. As noted by Edison and Kole (1994) and others, realignments tend to be associated with weakness in the U.S. dollar. The role of the dollar and the deutsche mark as international stores of value is the explanation for this. When the dollar is weak, investors substitute into deutsche mark-denomi nated assets. This increases the value of the deutsche mark not only with respect to the dollar but al so to other ERM currencies. This added pressure in times of crisis has frequently contributed to real ignments.

\section{CONCLUSIONS}

This article has surveyed recent work on forecasting real ignments and estimating the credibility of target zones. The literature has found that realignments are predictable to some extent within short intervals from readily available information such as interest rates and the position of the exchange rate within the band.

Most of the research surveyed here has taken the formation of expectations for granted and has used interest rate differentials which develop from those expectations as starting points for forecasting real ignments. The rel ati onship between realignment expectations and macrovariables is weak and uncertain. It is not clear how expecta-

${ }^{24}$ While generally described as an adjustable-peg fixed-rate

system, the Bretton Woods system is more accurately described as a narrow target zone system. The target zones were \pm 1 percent around dollar parities. 
ti ons are formed. Further, real ignments are said to "surprise" policymakers and market participants; realignment expectations rise only a short time before realignments. To some extent, this is to be expected. Although there are false al arms in which realignment expectations rise and then fall back agai n, once realignments are seen as likely, speculative pressure builds up that often results in a self-fulfilling speculative attack. Further research on the formation of expectations would be an important contribution.

\section{REFERENCES}

Bean, Charles R. "Economic and Monetary Union in Europe," The Journal of Economic Perspectives (fall 1992), pp. 31-52.

Bofinger, Peter, "The German Monetary Unification (Gmu): Converting Marks to D-Marks," this Review (July/August 1990), pp. 17-36.

Chen, Zhaohui, and Alberto Giovannini. "Estimating Expected Exchange Rates Under Target Zones," NBER Working Paper No. 3955 (January 1992).

Corbae, Dean, Beth Ingram, and Guillermo Mondino. "On the Optimality of Exchange Rate Band Policies," University of lowa Working Paper 90-04 (March 1990).

Coughlin, Cletus C., and Kees Koedijk. "What Do We Know About the Long-Run Real Exchange Rate?" this Review (January/February 1990), pp. 36-48.

Dueker, Michael J. "Hypothesis Testing with Near Unit-Roots: The Case of Long-Run Purchasing Power Parity," this Review (July/August 1993), pp. 37-48.

Edison, Hali J., and Eric O'N. Fisher. "A Long-Run View of the European Monetary System," Journal of International Money and Finance (March 1991), pp. 53-70.

and Linda S. Kole. "European Monetary Arrangements: Implications for the Dollar, Exchange Rate Variability and Credibility," Board of Governors of the Federal Reserve System, Division of International Finance (April 1994).

Engel, Charles, and Craig S. Hakkio. "Exchange Rate Regimes and Volatility," Federal Reserve Bank of Kansas City Economic Review (third quarter 1993), pp. 43-58.

Flood, Robert P., and Peter M. Garber. "Collapsing ExchangeRate Regimes: Some Linear Examples," Journal of International Economics (August 1984), pp. 1-13.

Frankel, Jeffrey, and Steven Phillips. "The European Monetary System: Credible At Last?," NBER Working Paper No. 3819 (August 1991).

Fratianni, Michele. "The European Monetary System: How Well Has It Worked?" Cato Journal (fall 1988), pp. 477-501.

Froot, Kenneth A., and Richard H. Thaler. "Anomalies: Foreign Exchange," The Journal of Economic Perspectives (summer 1990) pp. 179-92.

Higgins, Bryon. "Was the ERM Crisis Inevitable?" Federal Reserve Bank of Kansas City Economic Review (fourth quarter 1993), pp. 27-40.

Kaminsky, G. Faciela. "Is there a Peso Problem: Evidence from the Dollar/Pound Exchange Rate, 1976-1987," The American Economic Review (June 1993), pp. 450-72.
Koedijk, Kees G., and Clemens J. M. Kool. "Betting on the EMS," Open Economies Review (1993), pp. 151-73.

Kool, Clemens J. M. "The Case for Targeting Domestic Money Growth under Fixed Exchange Rates: Lessons from the Netherlands, Belgium, and Austria: 1973-1992," unpublished manuscript (October 1993).

Krugman, Paul, and Marcus H. Miller. "Why Have a Target Zone?" Centre for Economic Policy Research Discussion Paper Series No. 718 (October 1992).

Lindberg, Hans, Lars E. O. Svensson, and Paul Söderlind. "Devaluation Expectations: The Swedish Krona 1982-1991," NBER Working Paper No. 3918 (November 1991).

Macleod, Alexander, "After Currency Swings, Europe Seeks Order," The Christian Science Monitor, Wednesday September 30, 1992.

McCulloch, J. Huston. "Operational Aspects of the Siegel Paradox," The Quarterly Journal of Economics (February 1975), pp. 170-2.

Mizrach, Bruce. "Uncovering Interest Rate Parity in the ERM", Federal Reserve Bank of New York, unpublished manuscript (October 1993a).

"Mean Reversion in EMS Exchange Rates", Federal Reserve Bank of New York, unpublished manuscript (June 1993b).

"Target Zone Models with Stochastic Realignments: An Econometric Evaluation", Federal Reserve Bank of New York, unpublished manuscript (revised, April 1993c).

Neely, Christopher J. "Target Zones and Conditional Volatility: An ARCH Application to the EMS," Federal Reserve Bank of St. Louis Working Paper No. 94-008 (December 1993).

Obstfeld, Maurice. "Rational and Self-Fulfilling Balance-ofPayments Crises," The American Economic Review (March 1986), pp. 72-81.

"Balance-of-Payments Crises and Devaluation," Journal of Money, Credit and Banking (May 1984), pp. 208-17.

Pollard, Patricia S. "Central Bank Independence and Economic Performance," this Review (July/August 1993), pp. 21-36.

Rose, Andrew K., and Lars E. O. Svensson. "European Exchange Rate Credibility Before the Fall," NBER Working Paper No. 4495 (October 1993).

, and . "Expected and Predicted Realignments: The FF/DM Exchange Rate During the EMS," International Finance Discussion Paper Number 395, Board of Governors of the Federal Reserve System (April 1991).

Salant, Stephen W., and Dale W. Henderson. "Market Anticipations of Government Policies and the Price of Gold," Journal of Political Economy (August 1978), pp. 627-48.

Svensson, Lars E. O. "The Simplest Test of Target Zone Credibility," IMF Staff Papers (September 1991) pp. 655-65.

Ungerer, Horst, Jouko J. Hauvonen, Augusto Lopez-Claros, and Thomas Mayer, "The European Monetary System: Developments and Perspectives," IMF Occasional Paper No. 73 (November 1990).

Zurlinden, Mathias. "The Vulnerability of Pegged Exchange Rates: The British Pound in the ERM" this Review (September/October 1993), pp. 41-56. 